\title{
The Academic Triangle Implementation in Bogor New Normal Batik Village as a Collaborative Learning Center
}

\author{
Eneng Tita Tosida ${ }^{1 *}$, Fredi Andria ${ }^{2}$, Siti Warnasih $^{3}$, Novi Fajar Utami ${ }^{4}$, Elly Sukmanasa ${ }^{5}$, \\ Deden Ardiansyah ${ }^{6}$, Prihastuti Harsani ${ }^{7}$, Dinar Munggaran Achmad $^{8}$, Yuli Wahyuni ${ }^{9}$ \\ ${ }^{s 1,7,8}$ Computer Science Department, Faculty of Math and Science, Pakuan University, Bogor, Indonesia \\ ${ }^{2}$ Mangement Department, Faculty of Economic and Business, Pakuan University, Bogor, Indonesia \\ ${ }^{3}$ Chemistry Department, Faculty of Math and Science, Pakuan University, Bogor, Indonesia \\ ${ }^{4}$ Pharmacy Department, Faculty of Math and Science, Pakuan University, Bogor, Indonesia \\ ${ }^{6,9}$ Computer Technology Department, Vocational School, Pakuan University, Bogor, Indonesia
}

Corresponding author email: enengtitatosida@unpak.ac.id

\begin{abstract}
The main objective of this study is to build the new normal Bogor batik village which is integrated with collaborative learning, so as to create the academic triangle ecosystem. The academic triangle is cyclical in nature, which continues as an ecosystem of education, research and entrepreneurship (not only being an entrepreneur but an entrepreneurial spirit that never gives up in the face of all obstacles). This cycle involves lecturers and students who at the same time have a positive impact on improving the social economy and strengthening local culture. Hopefully, in the end, the ecosystem can become a laboratory for strengthening the academic triangle
\end{abstract}

Keywords: batik village, academic triangle, collaborative learning center

\section{Introduction}

Collaborative learning is carried out by two or more people to study together (Astuti Et Al., 2020)(Direktorat Jenderal Pendidikan Tinggi, Riset, 2021). One of the goals of collaborative learning is to provide opportunities for students to participate actively in the learning process or what is known as the student centre (Dian Anggreni et al., 2019). Based on the research of the World Economic Forum (WEF) 2020, there are 10 main abilities that are most needed to face the era of the Industrial Revolution 4.0, namely being able to solve complex problems, critical thinking, creative, human management skills, being able to coordinate with others, emotional intelligence, ability to assessing and making decisions, service-oriented, negotiation skills, and cognitive flexibility.

One of the $21^{\text {st }}$-century skills has to do with collaboration. This collaborative skill can be strengthened with digitalbased local wisdom. This refers to the sustainability of the 4.0 to 5.0 era or human society (Purwati \& Erawati, 2021), wherein in the 5.0 era the emphasis was on synergy with technology, which would later relate to sustainable development goals (SDGs). 21 $1^{\text {st }}$-century skills emphasize collaboration, communication, ICT literacy, creativity, critical thinking, problem-solving, and social and cultural competence. $21^{\text {st }}$-century skills prepare students to be able to find solutions to the complexities of modern society (Tosida et al., 2016). Skills such as reasoning, understanding the content of knowledge transfer as an effort to solve problems and determine appropriate solutions.

Tegal Village is one of nine villages in Kemang District, Bogor Regency. Tegal village has had the Role of Women towards Healthy and Prosperous Families activities(Tosida, Maryana, et al., 2017) but has not yet produced results that have an impact on improving the welfare of the residents. The results of the discussion show that in Tegal Village there is a group of women who have a business of painting on cloth but this micro-business is also powerless because 
it has not been able to produce a unique design, typical of Tegal Village (Tosida, Waluyo, et al., 2017a) and the scope of marketing is still limited in the group of recitation and teaching activities. other activities within the RT or RW. Sales capacity is still low (10 units per month).

The activity began with coordination with the District SME Diskop. Bogor and continued with the socialization of Entrepreneurship Village and Healthy Village, Tegal Village, Kec. Kemang. During the discussion process, the team also provided insight into the opportunities for micro-business in Bogor batik (Iskandar et al., 2017). The team, which was accompanied by a Bogor batik micro business actor (Darmin Kando Suhenda) explained the business and marketing processes as well as opportunities to improve welfare through the batik business, whose marketing was carried out in collaboration with schools to order school uniforms. Business groups, both the Role of Women towards Healthy and Prosperous Families and other business groups led by the chairman of RW 06 Desa Tegal (Sukma Wijaya) are enthusiastic to develop a batik business that carries the characteristics of Tegal Village. However, during the discussion, residents did not yet have the knowledge and skills about the batik production process, they also did not understand how to handle batik waste, and how to produce motif designs based on local wisdom or village characteristics.

The results of observations and in-depth interviews with these partners identified problem factors, namely 1) Partners did not know the batik production process, 2) Partners did not know how to handle batik waste which would later become the main problem, 3) Partners did not know how to design batik motifs based on village local wisdom, 4 ) Partners do not know simple bookkeeping, 5) Partners lack the ability to promote and market batik products.

Bogor's new normal batik village is a village formed by a service team as a form of service to the people of Tegal Village (Tosida et al., 2019),(Fauzi \& Defianisa, 2019). This is because with this socialization, it is expected that there will be active participation from the entire community of Tegal Village, especially the participation of PKK women or youth organizations or non-productive communities who have previously been appointed to the Batik Micro Business Group through the Decree of the Tegal Village Head who will be trained in batik making.

Based on the results of the analysis of partners as described above, the objectives of this program are 1) Providing batik production training to partners by bringing in instructors from experienced batik craftsmen, and at the same time developing a batik production site in Tegal Village, 2) Providing training about waste management in general and in particular batik liquid waste with resource persons who have been in the environmental field, especially waste management, and made waste installations, 3) Conduct comparative studies to batik galleries and provide training to partners to learn batik, 4) Provide bookkeeping training simple so that partners can control and calculate between capital and profit, 5) Provide training to partners in terms of promotion and marketing such as website creation, promotion through schools, and others.

\section{Literature Review}

Collaborative learning aims to determine a mind map on learning outcomes (Nisa et al., 2018). Collaborative learning is a collaborative skill. Cooperative skills are something that people really need in today's life (Nurhayati, 2020), because almost all behaviors in society show cooperation from all walks of life, regardless of ethnic, religious, racial, male and female differences, as well as group. To maintain and grow these activities, collaborative work is needed, which emphasizes mutual understanding, respect, responsibility, and tolerance (Fitriasari et al., 2020).

Moreover, the Indonesian people are facing problems in society in the form of inter-ethnic disputes, brawls between students and forms of incompatibility (disequilibrium) that can lead to national disintegration, so it is very important for students to be given an understanding of collaborative work in order to face the era of globalization which is full of with challenges and free competition. Thus, a close togetherness will be built between students so that it will be easier to solve problems together.

The Collaborative Learning Model Based on the Lesson Study Learning Communiy (LSLC)(Marhamah et al., 2017) implemented is Collaborative Learning carried out using a learning method using applications. Kab. batik introduction application. The first Bogor was carried out through AR Portal-based media which can also be used as a Virtual Expo and Bogor batik game. As it is known that due to the Covid-19 pandemic, exhibition activities are hampered, and this media can be used as a substitute for conventional exhibition activities, which are carried out through Virtual Expo media based on AR Portal(Khalifa et al., 2008). 
This Role Playing Game Educational Game for Recognition of Bogor Regency Batik Motifs is based on Role Playing Game (RPG)(Setiawan et al., 2017)(Aslan \& Balci, 2015). RPG is a type of game that focuses on roles and storylines that have a purpose. Player (players) are required to talk to other players to be able to reach the final goal. This educational game was built as an alternative media, to introduce and promote the batik motifs typical of Bogor Regency in the Batik Dayatri Gallery. Batik is a form of visual art on textile materials produced using traditional drawing techniques from Indonesia (Aryani \& Anggraeni, 2019)(Tosida, Waluyo, et al., 2017b). For the Javanese, batik is a traditional cloth that is integral to their cultural identity. Visuals on batik ornaments depict living speech and basic values in life (Minarno et al., 2014).

\section{Materials and Methods}

The activities carried out in the collaborative learning program are research-oriented and community service by building a new normal village of Bogor batik and healthy village Tegal village, Bogor district carried out with collaborative activities so that every element starting from universities and elements of the community feels the impact of the results of research and community service carried out by universities can provide added value, both socially and economically.

In accordance with the Main Performance Indicators of higher education institutions, in this case, Pakuan University in implementing MBKM, the method of implementing community service activities is carried out using the method shown in Figure 1. With the target of IKU MBKM, Pakuan University produces collaborative learning oriented towards community service.

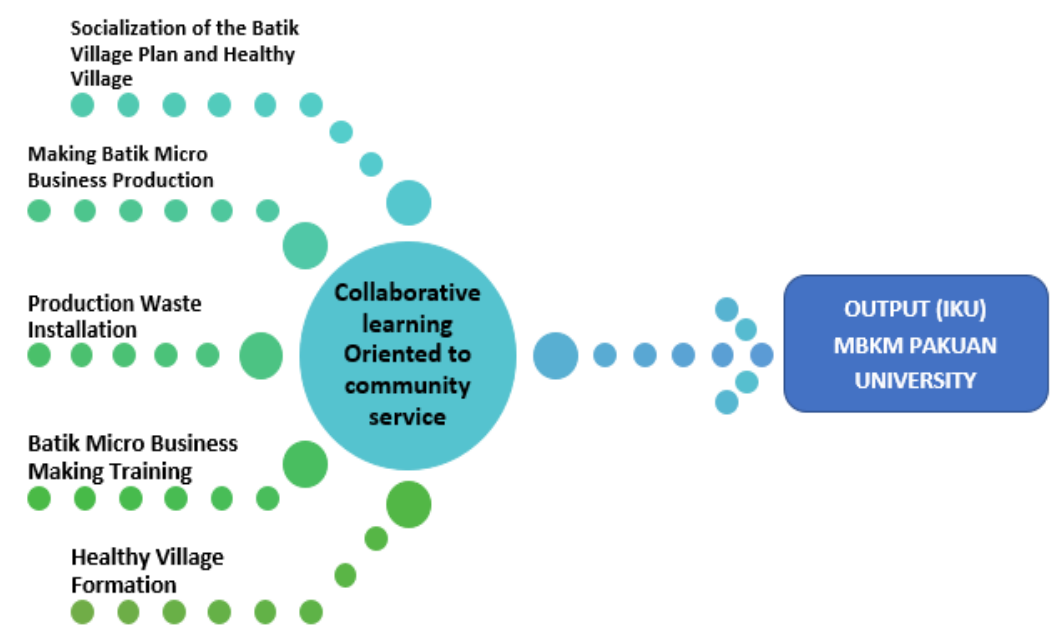

Figure 1 Methode

\section{Socialization of the Batik Village Plan and Healthy Village}

The socialization of the plan for the batik village and healthy village, Tegal village, Bogor district, includes two performance indicators of higher education institutions, especially the Pakuan University in carrying out higher education performance indicators related to the MBKM IKU. That is, students get experience from outside the campus and lecturers carry out activities outside the campus. In the event that students have off-campus experience, students can take lessons by way of socialization in the community so that students can get added value in accordance with the target performance needs of student graduates so that students can be accepted in the community with the knowledge they have.

The socialization of the plan for the batik village and healthy village in the village of Tegal, Kemang District, Bogor Regency has added value to the IKU lecturers carry out activities outside the campus by conducting research to produce research results in the form of a population survey (total sampling) on the implementation of the MBKM KPI program produced by private universities. 


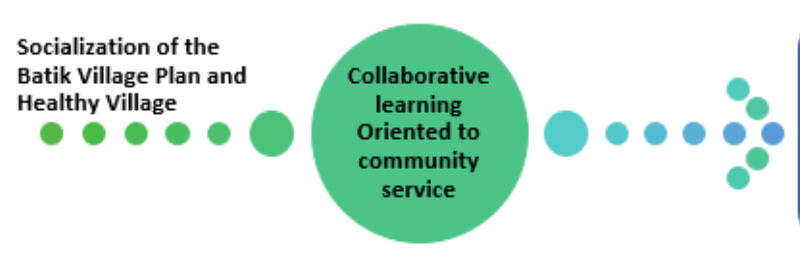

- Students Gain Off-

Campus

Experience

- Lecturer Activities outside campus

Figure 2 Methode of Sosialization

The socialization of Collaborative Learning in the Bogor Batik New Normal Village to students in schools in the Tegal Village, District, can be carried out well and smoothly because it is supported by several related parties, the socialization activity to schools aims to introduce Bogor New Normal Batik through exposure by way of the application of digital games introduction about the new normal Bogor batik. School residents are very supportive of the presence of the Abdimas Team, it looks like the welcome and seriousness in preparing students and teachers to take part in the activities we do when entering the school environment

\section{Community-Based Batik Micro Business Production}

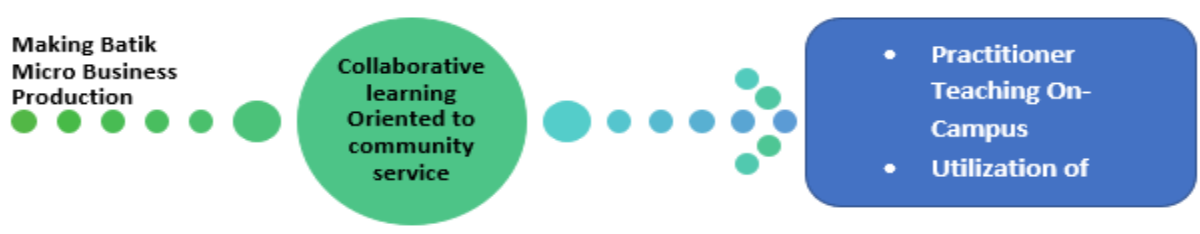

Figure 3 Methode Community-Based Batik Micro Business Production

Because business actors or workers in micro-batik businesses will have the opportunity to be exposed to residual pollutants from the batik production process, it is necessary to provide assistance to clean and healthy living habits. Among them by providing training on a clean and healthy lifestyle and skills to make healthy drinks. Program implementation and KPI achievement targets are shown in Figure 3.

\section{Conversion of Community Service Activities in Courses}

The process of establishing the Bogor New Normal Batik Village in Tegal Village, Kec. Kemang Kab. Bogor is based on the reference in Figure 23. Research collaboration and community service between lecturers and students is a necessity in the learning era that puts the concept of Independent Learning-Independent Campus forward. Collaboration is a way for lecturers to transmit their knowledge or expertise in conducting research and community service. So that students as learning objects are able to take many lessons in theoretical and practical concepts in the field.

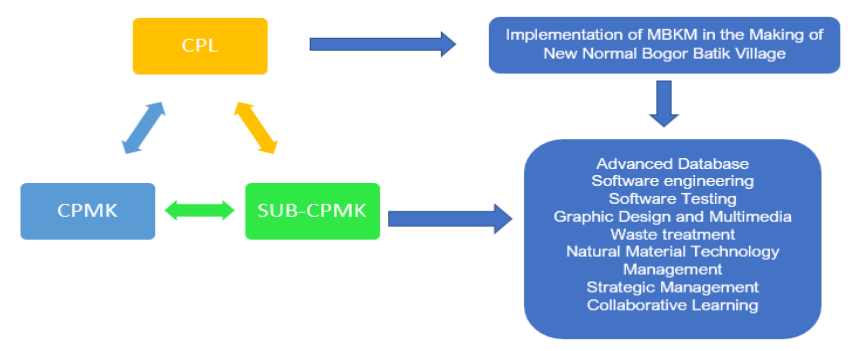

Figure 4 Conversion of Community Service Activities in Courses

\section{Results and Discussion}

The functions and benefits derived from the activities are felt by all parties involved. The following are the benefits felt by the community, students, and lecturers. Functions and Benefits for the Community are 1) The community has 
new knowledge related to the simple financial management of MSMEs. 2) The community has new skills in Tegal Village, Kemang District, Bogor Regency, namely making new normal Batik Bogor, 3) For the Tegal Village Government and Kemang District, it becomes the new ICON for Kemang District, Bogor Regency, related to SME Batik New Normal Bogor.

Functions and benefits for students 1)Students get course conversions, 2)Students can apply the learning outcomes of ATTITUDE, Knowledge, General Skills and Specific Skills for the study program. 3) Students are able to give positive social impact to the community. The functions and benefits for lecturers are 1) Lecturers can guide students in implementing MBKM, 2) Lecturers carry out tridharma, 3) Lecturers produce several publications from this activity.

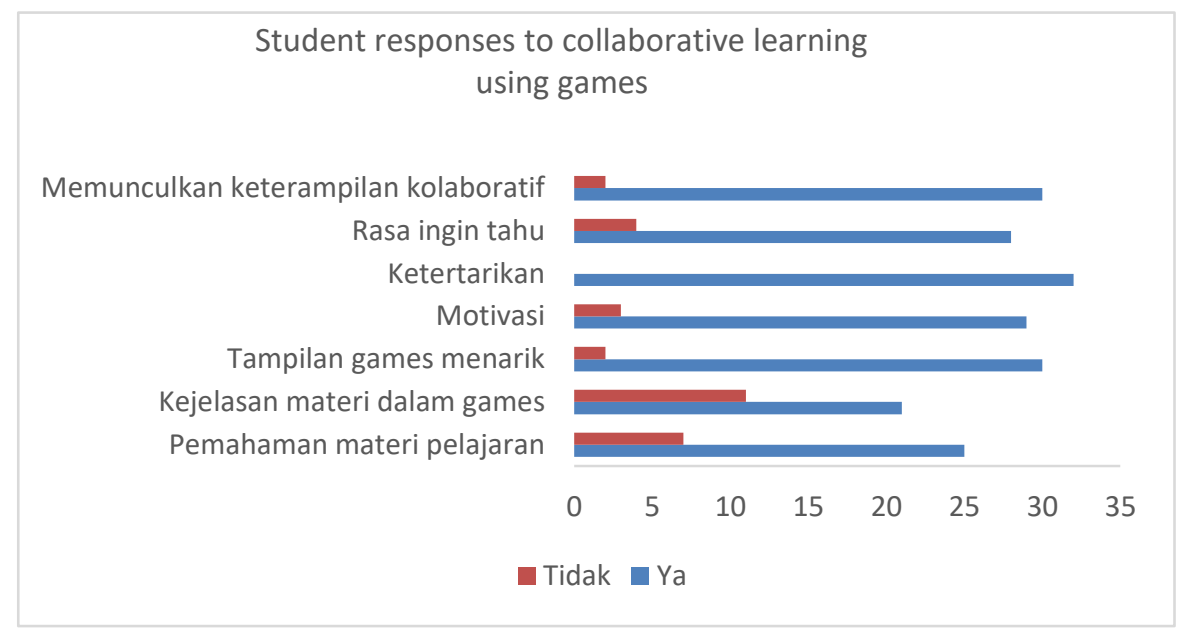

Figure 5 Student Understanding

Student responses can be said to be high in learning using media. This is in accordance with the research findings (Marisda \& Handayani, 2020). The student's response to each statement is said to be high as evidenced by the answer "Yes" above 20 people in each aspect. This finding shows that collaborative learning in an effort to introduce local wisdom using games media gets a good response (Sung \& Hwang, 2013). This response is because the use of media is a special attraction in learning. Other studies related to media prove that learning is successful with an increase in student learning outcomes. Thus, learning media should be used in learning, because the media is one of the tools used to attract and clarify the information conveyed by educators in learning. As a tool, media is defined as an inseparable part and of course it must be in accordance with the overall learning process. In other words, media selection is the use of media that allows students to interact with the selected media. The use of learning media improves learning outcomes, especially in the sub-themes of humans and the environment. there is a significant difference in the creative and friendly character between students who take part in learning with collaborative learning learning tools based on local wisdom and those who do not use developed learning tools. Thus, digital-based media, in this case games, will be able to motivate students to do collaborative learning. Where collaborative learning will foster collaboration skills which can later develop 21st century skills in other aspects such as critical thinking, communication skills, and being creative and innovative. Therefore, community service in the form of counseling can continue to be used as an effort in continuing education in accordance with the expected goals. Thus the hope towards era 5.0 related to human society will be realized, where this era emphasizes the synergy of technology with human resources. This means that mastery of technology can be used in skills in the world of work.

The economic and social impacts are felt directly by partner in Tegal Village Government, Kemang District, Bogor Regency. Economic and Social Impacts are direct and indirect or long term impacts. The direct impact is felt by the Tegal village community when the service is carried out. The indirect impact is felt when the service program is continued by the Tegal village community (Nor et al., 2012; Sung \& Hwang, 2013).

Direct Economic and Social Impact Service activities are carried out on December 16 to 30, 2021. In this service, there are several activities such as training, socialization, and soft launching. In this activity, the service team provided opportunities for MSMEs in Tegal Village to peddle or offer their products. Thus, the direct impact of the activity was felt positively by the MSMEs of Tegal village. 
The indirect economic and social impact will be felt by the people of the village of Tegal after the soft launching of the new normal Bogor batik village. This was proven when after the soft launching there was already an order for batik made by the Kemang sub-district government to make batik uniforms typical of the Kemang sub-district . In addition, batik orders have also started to arrive through social media built by the new normal Bogor batik village service team. New Normal Batik Village contributes to other industrial sectors in Tegal Village such as the convection sector, agriculture and the competitiveness of Tegal Village at the provincial and national levels.

\section{Conclusion}

Tegal Village, Kemang District, Bogor Regency has an activity to Increase the Role of Women towards Healthy and Prosperous Families which was initiated in 2020. However, it has not been able to significantly improve the welfare of the community. The results of team discussions with the Village Head, Head of the Role of Women towards Healthy and Prosperous Families and Head of RW 06 RT 05 Tegal Village has the characteristics and potential of village culture that have not been empowered. The team leader is experienced in empowering a batik micro business, Bogor Dayatri in the district. Cibinong, through the new normal batik design, promotions using gamebased digital learning media and marketing collaborations in schools. So that this success can be expanded and implemented in accordance with the expectations of the residents of Tegal Village to empower residents and mothers through the Role of Women towards Healthy and Prosperous Families, it is proposed to build the Bogor New Normal Batik Village (BNNB), so that a minimum of 3 new normal Bogor batik micro-businesses can be formed. This program has been initiated with the establishment of the New Normal Bogor Batik Micro Business Group in Tegal Village, Kec. Kemang, Bogor Regency.

This activity involved 5 lecturers and 15 students across fields including Computer Science, Chemistry, Elementary School Teacher Education, and Management study programs. The proposed program is based on the research results of Pakuan University lecturers including regarding the design of BNNB and digital learning media during the pandemic, waste reduction, related to healthy drinks and digital marketing for micro-enterprises Andria et al. (2020). The program outputs are the Independent Learning Campus Independent curriculum (MBKM) oriented to community service, the formation of three BNNB micro-enterprises, economic, social and cultural added value, program impact videos, articles in reputable international seminars and journals, on-line mass media publications. copyright of the Tegal BNNB motif design, the innovative product of the educational game Batik Quiz and the draft of the book.

\section{Acknowledgments}

The author would like to thank the Directorate General of Higher Education in 2021 for the Independent Learning Campus Research program (MBKM) and Community Service based on research results and the PTS Prototype of the Cooperation between Pakuan University and the Directorate General of Higher Education in 2021.

\section{References}

Aryani, A. S., \& Anggraeni, I. (2019). Design Database For Application Introduction Of Bogor Batik Motif Web-Based. Journal of Science Innovare. https://doi.org/10.33751/jsi.v2i2.1528

Aslan, S., \& Balci, O. (2015). Gamed: Digital educational game development methodology. SIMULATION. https://doi.org/10.1177/0037549715572673

Astuti, Y., Abidin, Y., \& Cahyani, I. (2020). Pembelajaran Menulis Kolaboratif Teks Eksplanasi Berbantuan Google Docs. Seminar Internasional Riksa Bahasa XIV.

Dian Anggreni, I. D. A. Y., Margunayasa, I. G., \& Kusmariyatni, N. N. (2019). Pengaruh Model Pembelajaran Kolaboratif Ditinjau Dari Motivasi Berprestasi Terhadap Hasil Belajar Ipa. Indonesian Journal Of Educational Research and Review, 2(2). https://doi.org/10.23887/ijerr.v2i2.17333

Direktorat Jenderal Pendidikan Tinggi, Riset, D. T. (2021). Panduan Pelaksanaan Bantuan Pendanaan Program Pembelajaran Kolaboratif Yang Berorientasi Pada Penelitian Dan Pengabdian Masyarakat. Direktorat Jenderal Pendidikan Tinggi, Riset, Dan Teknologi.

Fauzi, A. M., \& Defianisa, R. L. (2019). Analysis for cleaner production implementation strategy in batik industry in Bogor. IOP Conference Series: Earth and Environmental Science. https://doi.org/10.1088/1755-1315/325/1/012005 
Fitriasari, N. S., Apriansyah, M. R., \& Antika, R. N. (2020). Pembelajaran Kolaboratif Berbasis Online. Inspiration: Jurnal Teknologi Informasi Dan Komunikasi, 10(1). https://doi.org/10.35585/inspir.v10i1.2564

Iskandar, K., Jambak, M. I., Kosala, R., \& Prabowo, H. (2017). Current Issue on Knowledge Management System for future research: A Systematic Literature Review. Procedia Computer Science. https://doi.org/10.1016/j.procs.2017.10.011

Khalifa, M., Yan, A. Y., \& Ning, K. S. (2008). Knowledge management systems success: A contingency perspective. Journal of Knowledge Management. https://doi.org/10.1108/13673270810852430

Marhamah, Mustafa, \& Melvina. (2017). Pengaruh Model Pembelajaran Kolaboratif Berbasis Lesson Study Learning Community (Lslc). Jurnal Ilmiah Mahasiswa (JIM) Pendidikan Fisika, 02(3).

Marisda, D. H., \& Handayani, Y. (2020). Model Pembelajaran Kolaboratif Berbasis Tugas Sebagai Alternatif Pembelajaran Fisika Matematika. Prosiding Seminar Nasional Fisika, 2.

Minarno, A. E., Munarko, Y., Kurniawardhani, A., Bimantoro, F., \& Suciati, N. (2014). Texture feature extraction using cooccurrence matrices of sub-band image for batik image classification. 2014 2nd International Conference on Information and Communication Technology, ICoICT 2014. https://doi.org/10.1109/ICoICT.2014.6914074

Nisa, H., Disman, D., \& Dahlan, D. (2018). Pengaruh Penerapan Model Pembelajaran Kolaboratif Teknik Group Investigation Terhadap Kemampuan Berpikir Analisis Peserta Didik. Jurnal MANAJERIAL, 17(2). https://doi.org/10.17509/manajerial.v17i2.10277

Nor, M. Z. M., Abdullah, R., Selamat, M. H., \& Murad, M. A. A. (2012). An agent-based knowledge management system for collaborative software maintenance environment: Design and evaluation. Proceedings - 2012 International Conference on Information Retrieval and Knowledge Management, CAMP'12. https://doi.org/10.1109/InfRKM.2012.6205017

Nurhayati, N. (2020). Content Analysis tentang Pembelajaran Kolaboratif Berbasis Open Ended untuk Meningkatkan Kepercayaan Diri Siswa Dalam Belajar Matematika. Al-Khwarizmi: Jurnal Pendidikan Matematika Dan Ilmu Pengetahuan Alam, 8(2). https://doi.org/10.24256/jpmipa.v8i2.857

Purwati, N. K. R., \& Erawati, N. K. (2021). Pengembangan Buku Ajar Metode Numerik Berbasis Pembelajaran Kolaboratif. Mosharafa: Jurnal Pendidikan Matematika, 10(1). https://doi.org/10.31980/mosharafa.v10i1.817

Setiawan, B., Innatesari, D. K., Sabtiawan, W. B., \& Sudarmin, S. (2017). The development of local wisdom-based natural science module to improve science literation of students. Jurnal Pendidikan IPA Indonesia. https://doi.org/10.15294/jpii.v6i1.9595

Sung, H. Y., \& Hwang, G. J. (2013). A collaborative game-based learning approach to improving students' learning performance in science courses. Computers and Education. https://doi.org/10.1016/j.compedu.2012.11.019

Tosida, E. T., Ardiansyah, D., Walujo, A. D., \& Sofyandi, A. (2019). System Design of Augmented Reality Technology to Strengthen Sustainable Imaging of Kujang Products Based on Local Culture. International Journal of Recent Technology and Engineering. https://doi.org/10.35940/ijrte.d9016.118419

Tosida, E. T., Maryana, S., Thaheer, H., \& Damin, F. A. (2016). Visualization model of small and medium enterprises (SMEs) telematics services potentiality map in Indonesia. Proceedings of 2015 International Conference on Information and Communication Technology and Systems, ICTS 2015. https://doi.org/10.1109/ICTS.2015.7379890

Tosida, E. T., Maryana, S., Thaher, H., \& HArdiani. (2017). Implementation of Self Organizing Map (SOM) as decision support: Indonesian telematics services MSMEs empowerment. IOP Conference Series: Materials Science and Engineering, 755(1), 166. https://doi.org/10.1088/1742-6596/755/1/011001

Tosida, E. T., Waluyo, A. D., \& Suriansyah, M. I. (2017a). Sustainability And Imaging Of Local Wisdom Strengthening: Collaboration Of Eco-Edu Tourism. Qardhul Hasan: Media Pengabdian Kepada Masyarakat.

Tosida, E. T., Waluyo, A. D., \& Suriansyah, M. I. (2017b). Sustainability And Imaging Of Local Wisdom Strengthening: Collaboration Of Eco-Edu Tourism. Qardhul Hasan: Media Pengabdian Kepada Masyarakat, 3(2), 122-139. 